\title{
A history of vegetation, sediment and nutrient dynamics at Tivoli North Bay, Hudson Estuary, New York
}

\author{
Sanpisa Sritrairat ${ }^{a, *}$, Dorothy M. Peteet ${ }^{a, b}$, Timothy C. Kenna ${ }^{a}$, Ray Sambrotto ${ }^{a}$, Dorothy Kurdyla ${ }^{c}$, \\ Tom Guilderson ${ }^{\mathrm{c}}$ \\ a Lamont-Doherty Earth Observatory, 61 Rt. 9 W, Palisades, NY 10964, USA \\ ${ }^{\mathrm{b}}$ NASA Goddard Institute for Space Studies, 2880 Broadway, NY 10025, USA \\ ${ }^{\mathrm{c}}$ Lawrence Livermore Laboratories, Livermore, CA 94551, USA
}

\section{A R T I C L E I N F O}

\section{Article history:}

Received 18 August 2011

Accepted 1 March 2012

Available online 15 March 2012

\section{Keywords:}

paleoecology

tidal marshes

palynology

stable isotopes

nitrogen cycle

climate change

Medieval Warm period

Little Ice Age

European settlement

invasive species

Typha angustifolia

Phragmites australis

New York

\begin{abstract}
A B S T R A C T
We conduct a stratigraphic paleoecological investigation at a Hudson River National Estuarine Research Reserve (HRNERR) site, Tivoli Bays, spanning the past 1100 years. Marsh sediment cores were analyzed for ecosystem changes using multiple proxies, including pollen, spores, macrofossils, charcoal, sediment bulk chemistry, and stable carbon and nitrogen isotopes. The results reveal climatic shifts such as the warm and dry Medieval Warm Period (MWP) followed by the cooler Little Ice Age (LIA), along with significant anthropogenic influence on the watershed ecosystem. A five-fold expansion of invasive species, including Typha angustifolia and Phragmites australis, is documented along with marked changes in sediment composition and nutrient input. During the last century, a ten-fold sedimentation rate increase due to land-use changes is observed. The large magnitude of shifts in vegetation, sedimentation, and nutrients during the last few centuries suggest that human activities have made the greatest impact to the marshes of the Hudson Estuary during the last millennium. Climate variability and ecosystem changes similar to those observed at other marshes in northeastern and mid-Atlantic estuaries, attest to the widespread regional signature recorded at Tivoli Bays.
\end{abstract}

(c) 2012 Elsevier Ltd. All rights reserved.

\section{Introduction}

Projected warming, drought, sea level rise, and salt intrusion (Bindoff et al., 2007; Christensen et al., 2007) make Atlantic estuarine wetlands particularly vulnerable to future climate change. Alteration of wetlands within the estuary is especially of concern as wetlands serve many important ecosystem functions including hurricane protection, fish nursery habitat, and carbon storage. Understanding their resilience to past climatic shifts is paramount in providing a framework for their preservation and optimal function. Documenting ecosystem history provides multiple case studies of past ecosystem dynamics under quite varied environmental conditions (Jackson and Hobbs, 2009). However, such paleoecological data sets are rare, especially for the Hudson River Valley, New York, an extensive and intensively modified estuary.

\footnotetext{
* Corresponding author.

E-mail address: sanpisa@ldeo.columbia.edu (S. Sritrairat).
}

The Hudson River watershed is an important resource (Findlay et al., 2002b) for over 10 million people in large population centers such as the metropolitan area of New York City as well as in small communities along the river (Burns et al., 2007). Its rich natural ecosystem provides transportation and recreational function as well as a vital water supply. In the past few centuries, the Hudson watershed has been significantly altered. Anthropogenic impacts, such as wetland destruction, invasive species expansion, pollution, and erosion are all of concern (Mills et al., 1996; Templer et al., 1998; Caraco et al., 2000; Findlay et al., 2002a).

While lower Hudson wetlands have been the target of recent paleo-investigation (Pederson et al., 2005; Peteet et al., 2006), the mid-Hudson region contains freshwater peatland archives that have not been investigated. Hence, there is a need to identify this base-line information to assess past anthropogenic activities and climatic patterns in relation to projected shifts in climate and vegetation in the Mid-Hudson Valley region. Important questions arise -1 ) How much has climate change and human impact altered these important wetland riparian ecosystems? 2) What shifts in 
vegetation composition, sedimentation, and chemistry are apparent? and 3) Are there any detectable ecosystem and nutrient dynamic shifts after European settlement?

In this study, we examine how climate and human impacts have influenced plant ecology, invasive species expansion, habitat loss, carbon storage, and nutrient dynamics over the past millennium based on the multiproxy analysis of sediment cores using palynology, macrofossil, sedimentological, and geochemical analyses at the National Estuarine Research Reserve (NERR) Tivoli Bays, Hudson Estuary, NY. Comparison of these parameters from the marsh before and after European settlement allows identification of the recent human impacts on this estuarine ecosystem and provides insight regarding regional environmental changes.

\section{Study location}

The freshwater Tivoli Bays wetlands, $11 \mathrm{~km}$ north of the town of Red Hook, NY are the largest $\left(6.88 \mathrm{~km}^{2}\right)$ Hudson River National Estuarine Research Reserve (HRNERR) site on the Hudson (Fig. 1). The site consists of a mixture of tidal marsh, tidal swamps, mudflats, and subtidal shallow habitats, hosting narrowleaf cattail (Typha angustifolia), arrowhead (Sagittaria spp.), jewelweed (Impatiens capensis), spatterdock (Nuphar lutea), water celery (Vallisneria americana), non-native purple loosestrife (Lythrum salicaria), and non-native water chestnut (Trapa natans) along with a wide range of important fauna (Kiviat, 1983; Kiviat and Beecher, 1991). Adjacent rocky hillside forests are composed of oak (Quercus rubrum, Quercus prinus), maple (Acer rubrum, Acer saccharum), birch (Betula spp.) and ash (Fraxinus americana) with understory shrubs such as dogwood (Cornus florida) and river margins of alder
(Alnus sp.), willow (Salix sp.). The upland bedrock is composed of marine sedimentary rocks (shale and graywacke) and quartz (Isachsen et al., 2000). A continental climate affects the Hudson Valley region with a small river maritime influence. The area receives average annual precipitation of $1280 \mathrm{~mm}$, with average January and July temperature of $-4.2{ }^{\circ} \mathrm{C}$ and $22.2{ }^{\circ} \mathrm{C}$, respectively (NCDC, 2011) at nearby Poughkeepsie.

\section{Methods}

\subsection{Sampling}

We analyzed four sediment cores from three locations (Fig. 1). The area north of Cruger Island Road (Fig. 1) is called Tivoli North Bay, while the area south of the road is called Tivoli South Bay. Site Tivoli A (Fig. 1) is $15 \mathrm{~m}$ north of Cruger Island Road $\left(42^{\circ} 1.85^{\prime} \mathrm{N}, 73^{\circ}\right.$ $55.30^{\prime} \mathrm{W}$ ). A woody tidal swamp today, it retains a mixture of arrowhead (Sagittaria sp.), buttonbush (Cephalanthus occidentalis), alder (Alnus sp.), ash (Fraxinus sp.), and maple (Acer sp.). Core 05TivoliNB1 (Fig. 1) was taken in August 2005 using a Hiller peat corer and was used for the top $50 \mathrm{~cm}$ retrieval to prevent peat compaction. 05TivoliNB2, a 1-m core, was taken in November 2005 within $1 \mathrm{~m}$ of the first sampling site and retrieved using the modified Livingstone corer (Wright et al., 1984). These two cores are used for all analyses. 07Tivoli3, a core from Tivoli B, was taken with a Dashnowski corer from the second sampling site at the edge of the marsh in Tivoli North Bay ( $\left.42^{\circ} 1.98^{\prime} \mathrm{N}, 73^{\circ} 55.5^{\prime} \mathrm{W}\right), 12 \mathrm{~m}$ north of Cruger Island Road and $3 \mathrm{~m}$ from the railroad track (Fig. 1). This site is dominated by Typha angustifolia. The fourth core (Fig. 1), 07Tivoli4 $\left(42^{\circ} 1.81^{\prime} \mathrm{N}, 73^{\circ} 55.59^{\prime} \mathrm{W}\right)$, was taken from Tivoli $\mathrm{C}$, which

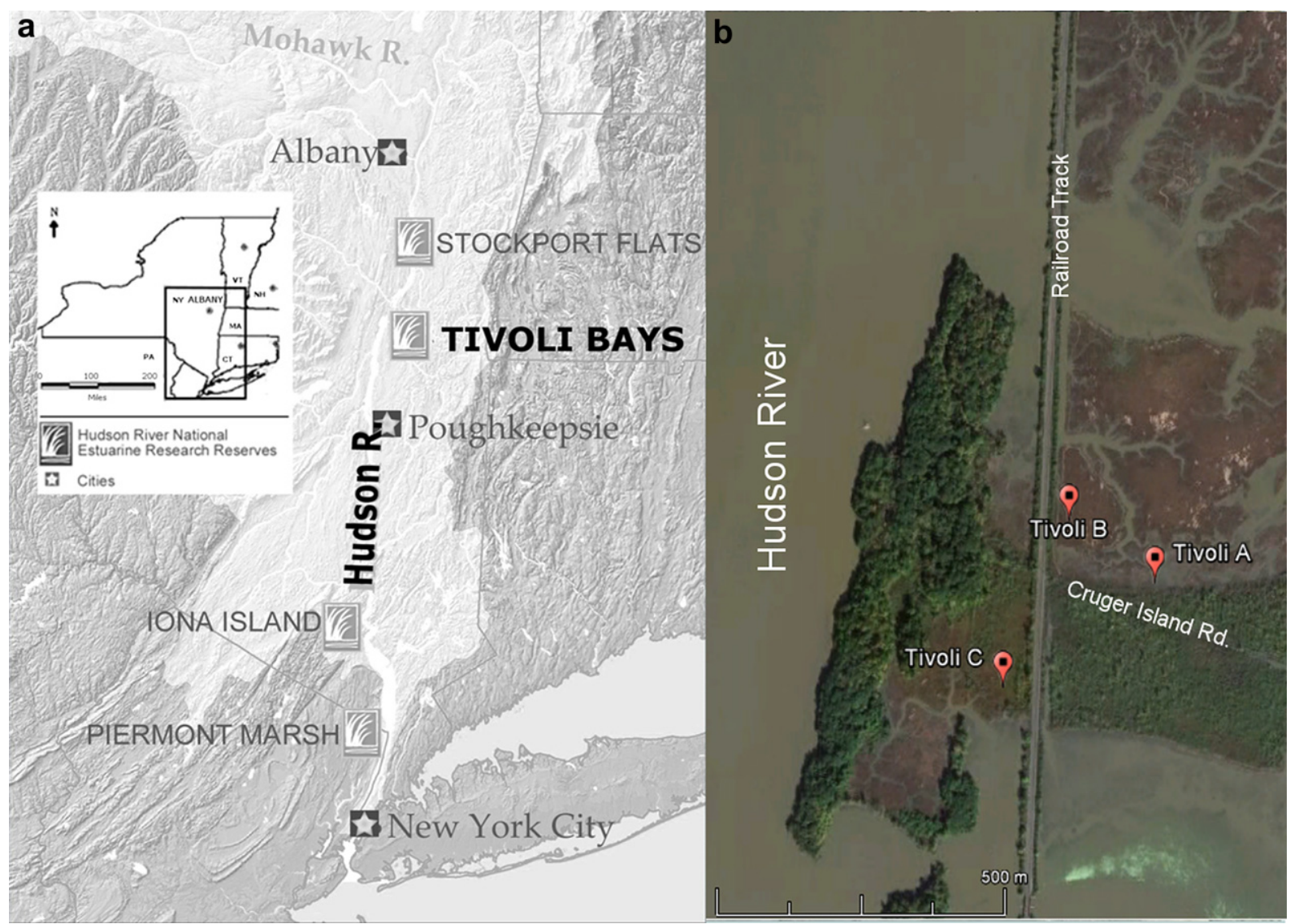

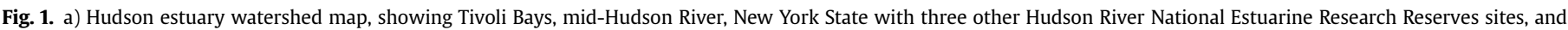
b) Three Tivoli Bays sampling sites. The sites are located 11 miles north of town of Red Hook north and south of Cruger Island Road. 
is $5 \mathrm{~m}$ west of the railroad in the South Bay and $20 \mathrm{~m}$ south of Cruger Island Road in T. angustifolia and Sagittaria spp.-dominated marsh. The cores were sub-sampled contiguously at $2 \mathrm{~cm}$ intervals, with an archive quarter stored at the LDEO repository. Approximately $10 \mathrm{cc}$ of homogenized samples from 05TivoliNB1 and 05TivoliNB2 were preserved wet for pollen and macrofossil analyses. The remainder of each sample was prepared for further analysis by drying at $105{ }^{\circ} \mathrm{C}$ and pulverizing with a mortar and pestle.

\subsection{Lithology}

Sediment lithology was analyzed based on visual inspection of color, texture, grain size, grain type, and fiber content using the USDA classification system. Sediment was delineated into different lithology types where sediment type abruptly changes based on these parameters.

\subsection{Loss-on-ignition (LOI)}

The dried samples were weighed and placed in a muffle furnace at $375{ }^{\circ} \mathrm{C}$ for $8 \mathrm{~h}$ (modified from Dean (1974).) The LOI is equal to sample weight lost as a result of combustion relative to the initial dry sample weight and representative of the amount of organic matter.

\subsection{X-ray Fluorescence spectroscopy}

Approximately $3 \mathrm{~g}$ of dried sediment was analyzed for chemical composition with X-ray Fluorescence spectroscopy (XRF) using Innov-X Alpha series 4000 XRF (Innov-X Systems, Woburn, MA) following protocols detailed by Kenna et al. (2011). Each analysis included two $120 \mathrm{~s}$ measurements using the soil protocol. Each sample was first analyzed in standard mode ( $\mathrm{Pb}$ and $\mathrm{Zn}$ in this study) and then in Light Element analysis mode (K for this study).

\subsection{Gamma ray spectroscopy}

After being sealed for $\sim 3$ weeks to allow for short-lived ${ }^{238} \mathrm{U}$ series radionuclides to re-establish equilibrium, approximately $3-6 \mathrm{~g}$ of dried sediment from the top $50 \mathrm{~cm}$ of core 05TivolinB1 were analyzed at 2-cm intervals for gamma emitting radionuclides. The gamma counting system was comprised of a Canberra HpGe well detector model GCW2022 connected to a multi-channel buffer (Ortec model 919 Spectrum Master; 16,384 channels) and a personal computer running the MAESTRO $^{\odot}$ multi-channel analyzer emulation software package (Ortec). Detector efficiencies were determined by counting an International Atomic Energy Agency standard (IAEA-375) and U.S. Environmental Protection Agency standard pitchblende ore (SP-1). Corrections to the measured radionuclide counts included background, counting efficiency, geometry, branching ratio, and dry sample mass to obtain activity per dry weight gram. ${ }^{210} \mathrm{~Pb}$ activities were corrected for self-attenuation (Appleby et al., 1992). Excess ${ }^{210} \mathrm{~Pb}$ was calculated by subtracting the ${ }^{226} \mathrm{Ra}$ from the total ${ }^{210} \mathrm{~Pb}$. Excess ${ }^{210} \mathrm{~Pb}$ and ${ }^{137} \mathrm{Cs}$ activities were then decay corrected to core collection date. The precision of the measurement was $\pm 2-10 \%$, and the background levels were all $<0.05 \mathrm{cpm}$.

\subsection{Radiocarbon dates}

Identified macrofossils were selected and radiocarbon dated using an Accelerator Mass Spectrometer (AMS) at Lawrence Livermore National Laboratory. Radiocarbon dates were calibrated to calendar dates using the CALIB program, version 6.0 of Stuiver and Reimer (1993).

\subsection{Pollen, spore, and charcoal analysis}

Wet sediments were processed for pollen analysis with the standard $\mathrm{HCl}, \mathrm{HF}$, and acetolysis treatment, along with 7 and $150 \mu \mathrm{m}$ filtration and centrifugation to extract the pollen and spore fraction (Faegri and Iversen, 1975). Exotic Lycopodium spores were added to calculate pollen concentration. Identification was based on pollen identification keys and LDEO reference pollen (Faegri and Iversen, 1975; Kapp, 2000; Finkelstein, 2003). Typha angustifolia was carefully separated from other Typha species and from Sparganium based on its shape and structure (Finkelstein, 2003). Phragmites australis pollen was separated from other Poaceae based on its smaller size than other Poaceae spp. in tidal marshes (Clark and Patterson, 1985). A minimum of 300 identifiable pollen grains for each sample were counted at $400 \times$ magnification. Pollen percentage was calculated based on total pollen sum, excluding spores. Charcoal counts included only charcoal pieces $>250 \mu \mathrm{m}^{2}$. Charcoal is presented as charcoal to total pollen (charcoal:pollen) ratio.

\subsection{Macrofossil analysis}

Five $\mathrm{cm}^{3}$ aliquots of wet samples were passed through a $500 \mu \mathrm{m}$ sieve and rinsed with water. Material retained on the sieve was suspended in water and examined under a microscope at up to $80 \times$ magnification. Macrofossils were identified using an extensive reference seed collection at LDEO and plant identification keys (Fernald, 1970; Martin and Barkley, 1973; Montgomery, 1977).

\subsection{Total $C$ and $N$ and stable $C$ and $N$ isotope analysis}

Dried and ground samples were weighed into tin cups (1-2 mg per sample). Three replicates of each sample were analyzed on a CHNS/O analyzer (2400 Series II, Perkin-Elmer, Boston, MA, USA) with combustion and reduction temperature of $925^{\circ} \mathrm{C}$ and $640{ }^{\circ} \mathrm{C}$ for $\mathrm{C}$ and $\mathrm{N}$ content respectively. Acetanilide (1-2 $\mathrm{mg}$ ) was used as standard and was run every 10 samples to ensure the machine's stability. Carbon and nitrogen fluxes are calculated as \%C (or N) $\times$ bulk density $\times$ sedimentation rate.

Three other replicates of each sample were analyzed using a PDZ Europa 20-20 mass spectrometer with an ANCA-SL combustion system (Crewe, UK). The system measures total C, total $\mathrm{N}, \delta^{13} \mathrm{C}$ and $\delta^{15} \mathrm{~N}$. The delta $(\delta)$ notation refers to the following ratio (R) of rare versus abundant isotope of either $\mathrm{C}$ or $\mathrm{N}$ with respective standard (PD-Belemnite and air respectively) according to Craig (1957), where

$\delta($ in $\%)=\left(\frac{R_{\text {sample }}}{R_{\text {standard }}}-1\right) 1000$

A student $t$-test (two-tail) was performed to determine if two groups of dataset are significantly different.

\section{Results}

\subsection{Lithology, LOI and sediment chemistry}

Four sediment types comprise the upper $100 \mathrm{~cm}$ of the cores (Fig. 2). From 100 to $66 \mathrm{~cm}$, the sediment is composed of fine black peat muck with fibrous material. From 66 to $52 \mathrm{~cm}$, the dark sediment is very fine. The lithogenic fraction of the top two zones is composed of well -sorted gray silty clay, though the lower zone is darker. A significant color change from dark gray to a lighter gray 

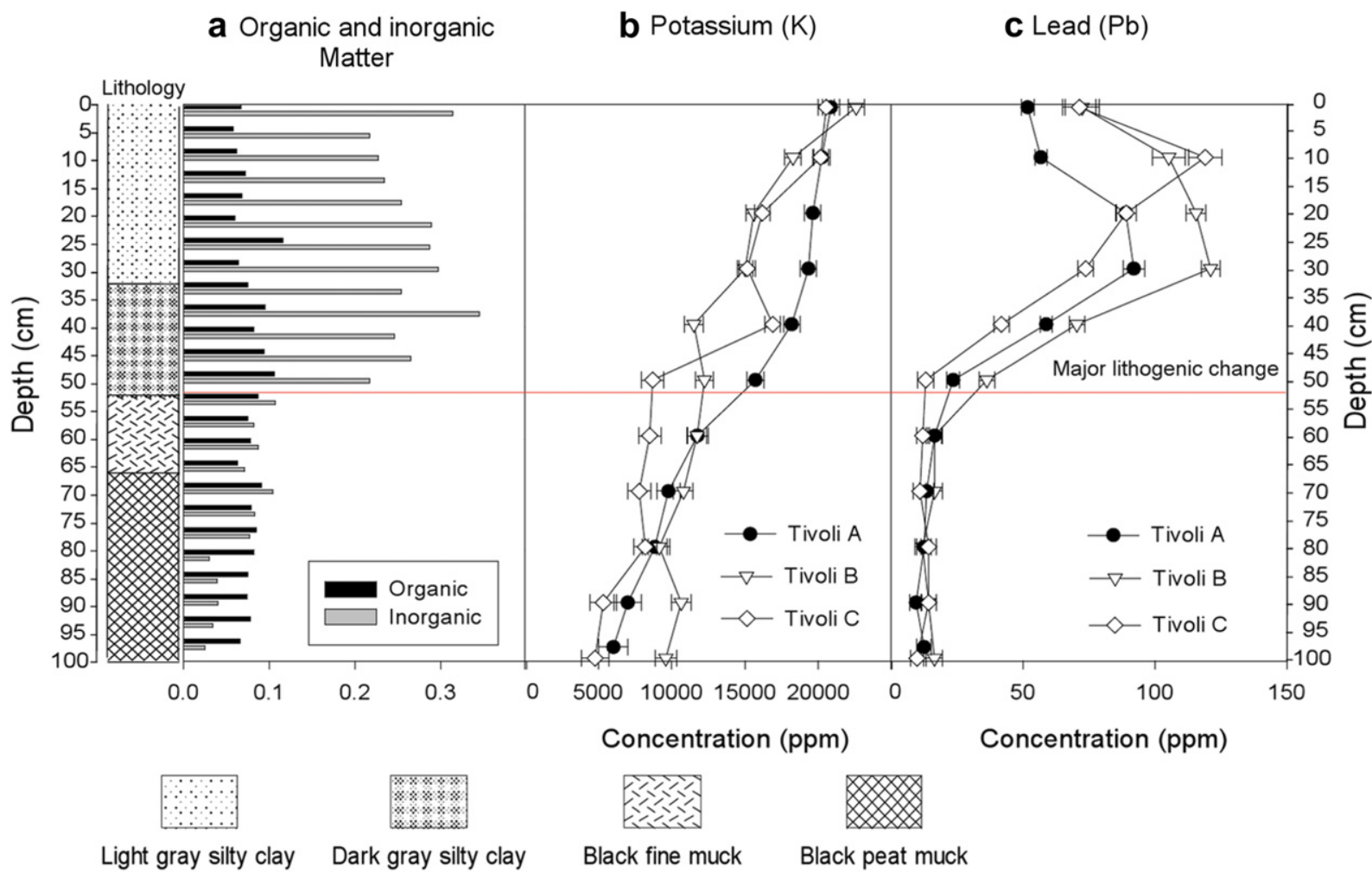

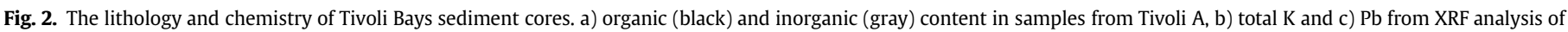

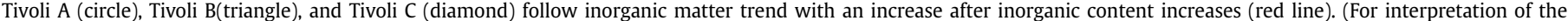
references to colour in this figure legend, the reader is referred to the web version of this article).

color occurs at $32 \mathrm{~cm}$. Organic matter fluctuates between 0.8 and $1.1 \mathrm{~g} \mathrm{~cm}^{3}$. Inorganic matter content increases abruptly at $52 \mathrm{~cm}$ (Fig. 2), and remains elevated to the surface. This corresponds to a $\mathrm{K}$ concentration increase above $50-60 \mathrm{~cm}$ at all three locations (Fig. 2), paralleling a major sedimentation change with higher inorganic matter input. Other lithogenic indicators, such as Ti (not shown), follow a similar trend as $\mathrm{K}$. The concentration of trace metals, including total $\mathrm{Pb}$ (Fig. 2), of all sites also increases after 50-60 cm depth, indicating that the lithogenic and chemistry change above these depths happened in the early 20th century (Nitsche et al., 2010).

\subsection{Chronology}

In order to estimate the sediment accumulation rates in the upper portion of the core, we used the constant flux: constant sedimentation (CFCS) excess ${ }^{210} \mathrm{~Pb}$ model (Krishnaswami et al., 1971; Robbins et al., 1978), fitting an exponential curve to the excess ${ }^{210} \mathrm{~Pb}$ activity versus depth (Fig. 3a). Excess ${ }^{210} \mathrm{~Pb}\left({ }^{210} \mathrm{~Pb}_{\mathrm{xs}}\right)$ activities ranged between below detection and $3000 \mathrm{pCi} / \mathrm{kg}^{210} \mathrm{~Pb}_{\mathrm{xs}}$ is complicated in this core. Evidence of disturbance in the profile can be observed at $20 \mathrm{~cm}$. Values fall below detection at $32 \mathrm{~cm}$, indicating perhaps a second discontinuity. Sedimentation rates estimated for intervals $0-20$ and 20-32 independently are similar ( 0.8 and $0.74 \mathrm{~cm} / \mathrm{yr}$, respectively, Fig. 3a).

The excess ${ }^{210} \mathrm{~Pb}$ age model yields deposition ages between 1961 and 1972 for intervals between 24 and $30 \mathrm{~cm}$ (Fig. 3b), which contain the ${ }^{137} \mathrm{Cs}$ maximum. The timing is consistent with global fallout deposition related to atomic weapons tests (Hardy, 1977; Monetti, 1996). We also observe above background levels of $\mathrm{Pb}$ and Zn (Figs. 2and 3), metals that are associated with anthropogenic industrial activities above $50 \mathrm{~cm}$ at all sites. The agreement between independent chronostratigraphic indicators provides a measure of confidence in the chronology above $32 \mathrm{~cm}$ and also suggests that the disturbance observed at $20 \mathrm{~cm}$ is minor.

Deposition ages between 32 and $52 \mathrm{~cm}$ are less certain based on ${ }^{210} \mathrm{~Pb}$. However, the continued presence of total $\mathrm{Pb}$ and total $\mathrm{Zn}$ (Fig. 3) allows us to constrain the timing to the early 20th century (Nitsche et al., 2010). Extrapolation of the excess ${ }^{210} \mathrm{~Pb}$ derived sedimentation rate of $0.74 \mathrm{~cm} / \mathrm{yr}$ yields a deposition age of $\sim 1930$ for the discontinuity at $52 \mathrm{~cm}$.

The depth to age relationship below $52 \mathrm{~cm}$ is based on two ${ }^{14} \mathrm{C}$ dates for macrofossils collected at 85 and $99 \mathrm{~cm}$ (Table 1) which yields a sedimentation rate of $\sim 0.05 \mathrm{~cm} / \mathrm{yr}$ (Fig. 4). If one applies the ${ }^{14} \mathrm{C}$ based sedimentation rate, the deposition age of the base of the discontinuity at $52 \mathrm{~cm}$ is $\sim 1740 \mathrm{AD}$ (Fig. 4), which is consistent with the timing of the European Settlement of the early 18th century. Although there is evidence of some disturbance/discontinuity in the sedimentary record, information obtained from the application of multiple independent chronostratigraphic indicators is consistent, suggesting that sediments obtained from Tivoli Bays can provide a robust comparison of two distinct time frames before and after the European settlement. The consistent depositional patterns at three sites suggest that the lithogenic changes are widespread in the marsh.

\subsection{Pollen and spore assemblages and charcoal}

Based on visual inspection in Fig.5, the pollen stratigraphy from 100 to $0 \mathrm{~cm}$ can be divided into four pollen assemblage zones. The pollen concentration profile yields a similar pattern and thus the concentration profile is omitted. Fig. 6 illustrates a simplified diagram of non-invasive, invasive, and woody wetland species to illustrate ecological compositional shifts. 

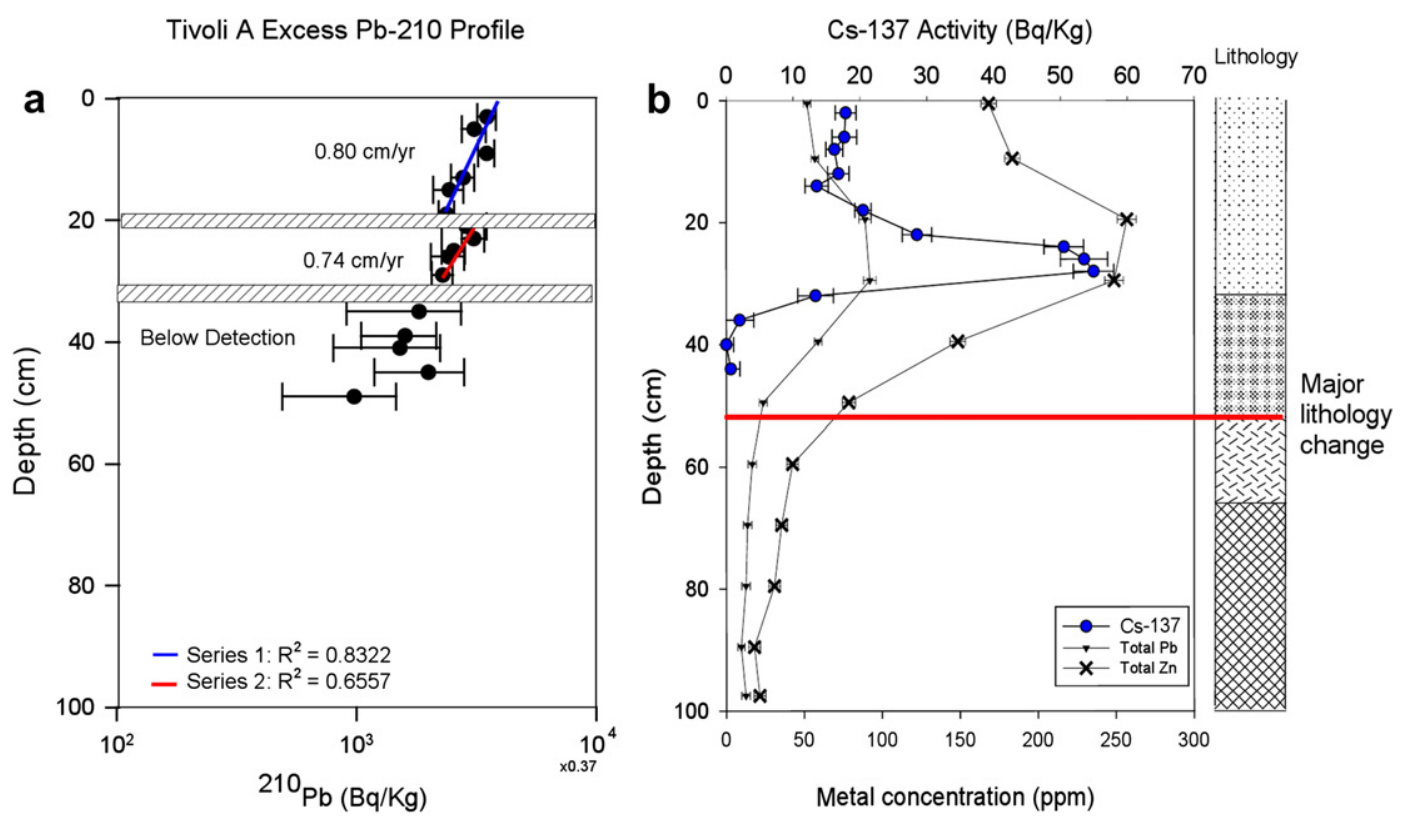

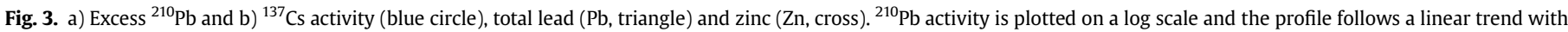

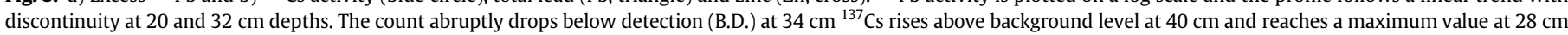

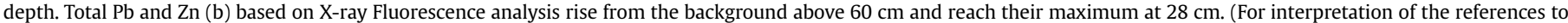
colour in this figure legend, the reader is referred to the web version of this article.)

\subsubsection{Zone 1: Quercus-Pinus-Betula-Carya-Osmunda $(100-78 \mathrm{~cm})$}

Quercus (22-30\%), Pinus (13-20\%), Betula (7-10\%), Carya (3-5\%), and Osmunda (18-25\%) reach maximum percentage in this zone. Poaceae (10-17.5\%), Cyperaceae (12-22\%) and Polypodiaceae (10-22\%) percentages are also relatively high. Picea (2.5\% average) is consistently visible in this zone. Charcoal increases abruptly in the upper half of the zone from 92 to $78 \mathrm{~cm}$ and is close to the maximum for the entire core.

\subsubsection{Zone 2: Quercus-Pinus-Tsuga-Cyperaceae-Poaceae-}

Polypodiaceae-Osmunda $(78-52 \mathrm{~cm})$

Quercus (18-22\%) and Pinus (10-15\%) remain the two dominant arboreal species. Populus reaches its maximum (8\%) at $70 \mathrm{~cm}$ and Tsuga reaches maximum values. Pollen of herbaceous taxa account for $35-45 \%$, with Cyperaceae (25-35\%) increasing abruptly and Poaceae declining toward the top of the zone. Polypodiaceae reaches maximum values, and Osmunda remains high but declines toward the upper portion of the zone. Nymphaea was present throughout the zone. Charcoal:pollen reaches the maximum value in the lower part of the zone at $74-72 \mathrm{~cm}$.

\subsubsection{Zone 3: Quercus-Alnus-Poaceae-Ambrosia-Typha} $(52-36 \mathrm{~cm})$

The arboreal fraction is comprised mostly of Quercus (10-15\%) and Alnus (20-25\%). Percentages of Tsuga and Pinus decline to minimum values of $5 \%$ in this zone. Betula declines at the

Table 1

AMS radiocarbon dates of Tivoli bays core.

\begin{tabular}{|c|c|c|c|c|c|}
\hline $\begin{array}{l}\text { Lab } \\
\text { Number }\end{array}$ & Depth & $\begin{array}{l}\text { Materials } \\
\text { dated }\end{array}$ & $\begin{array}{l}\text { Uncorrected } \\
{ }^{14} \mathrm{C} \mathrm{Age}^{\mathrm{a}}\end{array}$ & $\begin{array}{l}95.4 \% \\
(2 \sigma) \text { cal } \\
\text { age ranges } \\
\text { (area) }\end{array}$ & $\begin{array}{l}\text { Selected } \\
\text { calendar } \\
\text { age (AD) }\end{array}$ \\
\hline N74940 & $\begin{array}{l}84-86 \\
\mathrm{~cm}\end{array}$ & $\begin{array}{l}2 \text { Rosaceae } \\
\text { seeds and } 1 \\
\text { Carex seed }\end{array}$ & $965 \pm 35$ & $\begin{array}{l}1015-1160 \\
(85 \%)\end{array}$ & 1087.5 \\
\hline N85635 & $98-100$ & 1 Carex seed & $1250 \pm 90$ & $\begin{array}{l}645-977 \\
(95 \%)\end{array}$ & 811 \\
\hline
\end{tabular}

${ }^{\mathrm{a}}$ With two standard deviation age range as calibrated by CALIB 6.0. beginning of the zone, but starts to increase at $40 \mathrm{~cm}$. Ambrosia, Chenopodiaceae, Poaceae and Impatiens markedly increase, concurrent with a rise in Salix and Cephalanthus, while Polypodioceae and Osmunda sharply drop.

\subsubsection{Zone 4: Quercus-Pinus-Betula-Typha-Poaceae $(36-0 \mathrm{~cm})$}

Quercus and Pinus recover, with a rising trend reaching the maximum of 25 and 15\% respectively. Betula (8\%) recovers its high percentage as Ambrosia declines. Typha angustifolia (30-60\%) becomes dominant. Salix, Fraxinus, Cephalanthus, Vitis, and Violaceae continue to increase. Lythraceae and Myriophyllum can consistently be observed throughout the zone. Other aquatic taxa, including Nymphaea and Potamogeton become noticeable. The charcoal:pollen ratio declines to less than 30 , but then slightly increases mid-zone.

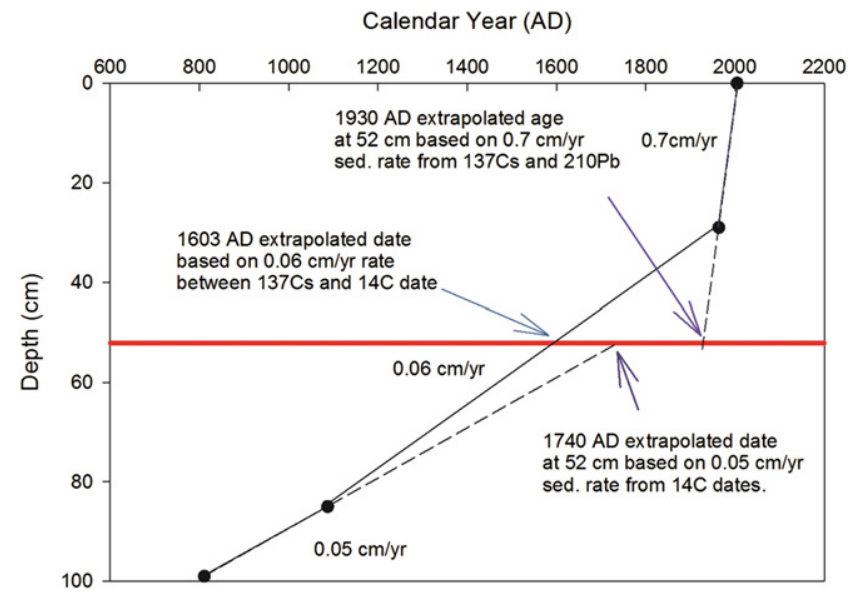

Fig. 4. Age-depth relationship of Tivoli A. An extrapolation based on AMS ${ }^{14} \mathrm{C}$ age below $52 \mathrm{~cm}$ of the core at $0.05 \mathrm{~cm} / \mathrm{yr}$ suggests that the $52 \mathrm{~cm}$ boundary is dated back to $1740 \mathrm{AD}$. An extrapolation using $0.74 \mathrm{~m} / \mathrm{yr}$ sedimentation rate in the upper $52 \mathrm{~cm}$ suggests that the $52 \mathrm{~cm}$ depth is dated to $1930 \mathrm{AD}$. 


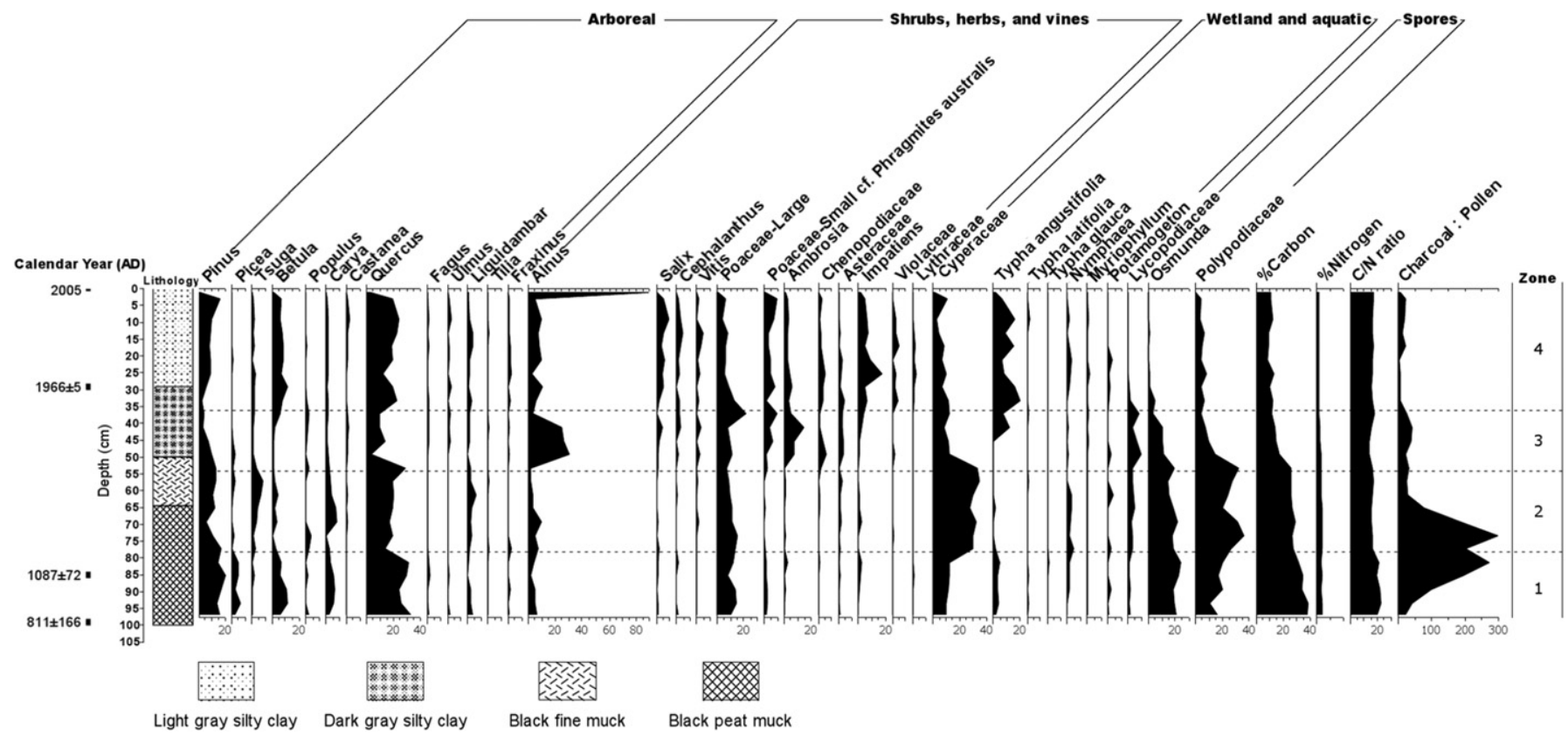

Fig. 5. Tivoli Bays pollen percentage profile. Percentage is calculated in relation to total pollen sum and is categorized by vegetation type.

\subsection{Macrofossil assemblages}

The macrofossil diagram is presented in Fig. 7 utilizing the same zones as in Fig. 5. Very few macrofossils are found in the lowermost zone (Fig. 7). Carex cf. aquatilis seeds throughout zone 2 are concurrent with Cyperaceae pollen increases in zone 3 (Fig. 5). Seeds of weedy species, including Asteraceae, Poaceae, Polygonum, Impatiens capensis and Chenopodiaceae are found primarily in the top zones (zone 3 and 4). However, both pollen and seeds of $I$. capensis were observed in earlier zones as well.

The macrofossils provide the advantage of confirming the presence of some plants as well as aiding identification at the species level. For example, Cornus obliqua seeds (zone 3) were found, though their pollen were not recognized in the pollen profile. Alnus bracts were found in zone 1, 2 and 4, even though Alnus pollen percentage is the highest in zone 4 only. Violet seeds are also found at several depths throughout, even though Violaceae pollen (Fig. 5) is the highest in zone 4.

\section{5. $\% \mathrm{C}, \% \mathrm{~N}$, and $\mathrm{C} / \mathrm{N}$ ratio}

Hydrogen to carbon $(\mathrm{H} / \mathrm{C})$ atomic ratio ranges from 0.98 to 1.45 , indicating a low inorganic carbon fraction. Percent carbon and $\mathrm{C} / \mathrm{N}$ ratio both show overall declines upward (Fig. 8). In zone 1, percent carbon decreases from $39 \%$ to $28 \%$ in this lowermost part of the core (Fig. 8). The $\mathrm{C} / \mathrm{N}$ ratio in this zone from 98 to $80 \mathrm{~cm}$ is significantly higher than the rest of the core $(P<0.001)$, with a mean value of $20.6 \pm 1.5$. Percent carbon declines slightly in zone $2(26.6 \pm 1.1 \%)$, while percent nitrogen $(1.66 \pm 0.13 \%)$ and the $\mathrm{C} / \mathrm{N}$ ratio $(16.0 \pm 0.7 \%)$ are very stable during this interval. In zone 3 , percent carbon gradually drops by half, from $25 \%$ to $12 \%$ over this interval. Percent nitrogen follows a similar decreasing trend, changing from $1.6 \%$ to $0.7 \%$. There is a slight decline of the $\mathrm{C} / \mathrm{N}$ ratio where charcoal also drops, but both increase at the close of the interval. In zone 4, percent carbon content fluctuates around $11.0 \pm 1.9 \%$. Percent nitrogen is highly variable $(0.668 \pm 0.107 \%)$, while the $\mathrm{C} / \mathrm{N}$ ratio is stable (16.5 $\pm 0.7 \%)$.

\section{Calendar Year (AD)}

\section{$\%$ Pollen and Spores}

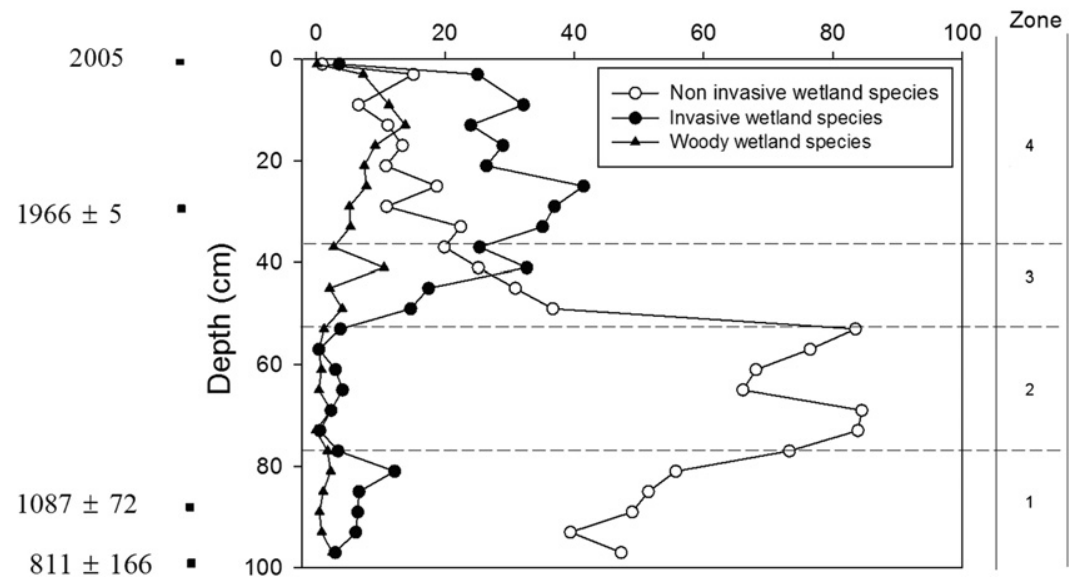

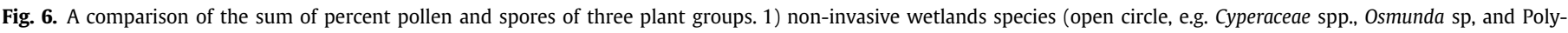

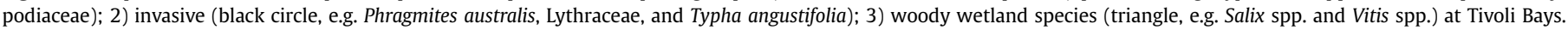




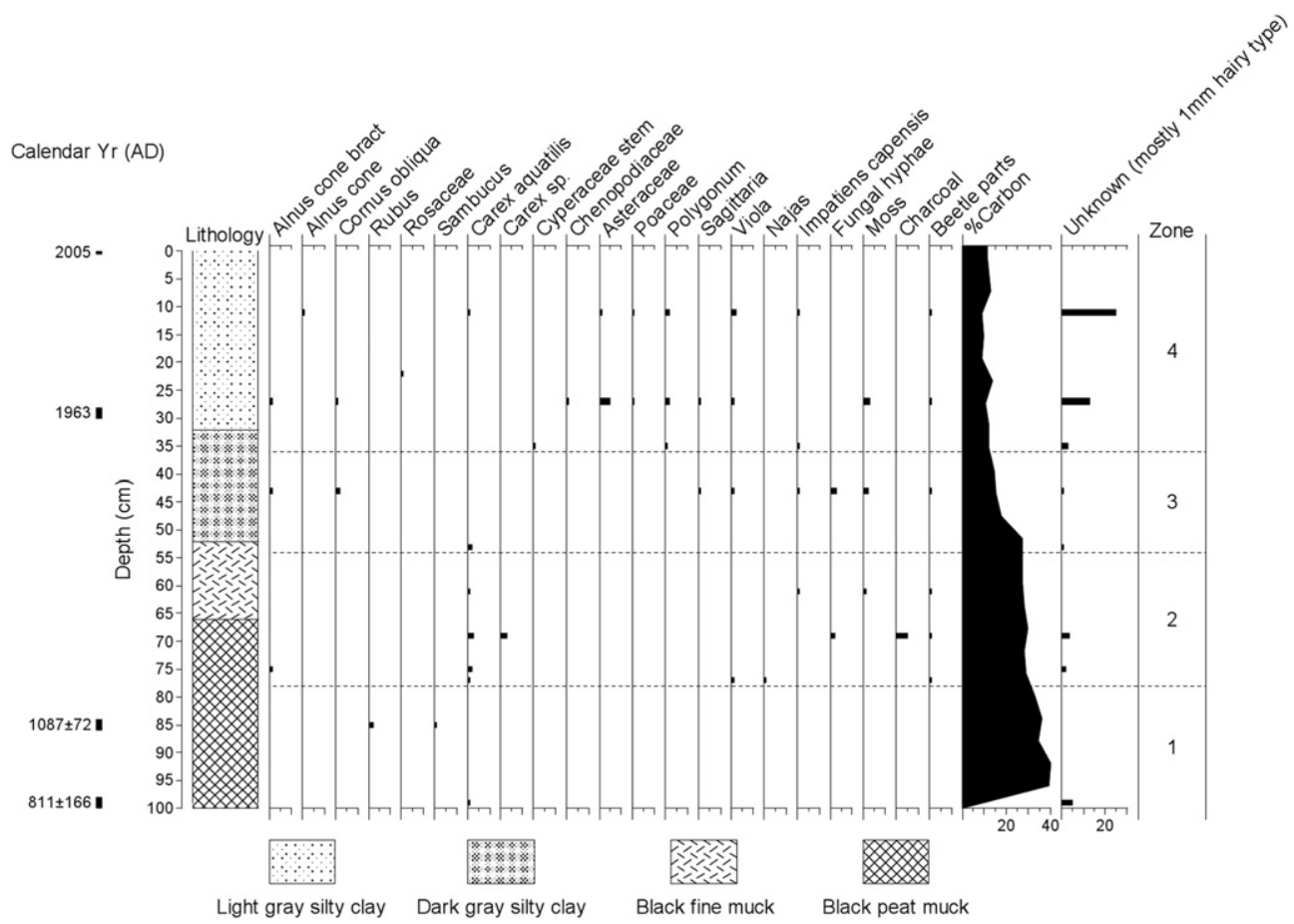

Fig. 7. Macrofossils identified in Tivoli North Bay core. The fossils are larger than $150 \mu \mathrm{m}$ and are seeds unless specified otherwise, in the unit of count per $5 \mathrm{~cm}^{3}$.

\subsection{Stable $C$ and $N$ Isotopic analysis}

Stable isotope $\mathrm{C}$ and $\mathrm{N}$ show significant fluctuations throughout the core (Fig. 8). The $\delta^{13} \mathrm{C}$ is stable at lower depths from 93 to $57 \mathrm{~cm}$, with the mean value of $-26.52 \pm 0.37 \%$ Above $57 \mathrm{~cm}$ depth, the $\delta^{13} \mathrm{C}$ increases, until reaching a maximum value of $\delta^{13} \mathrm{C}$ $(-22.82 \pm 0.46 \%)$ at $47 \mathrm{~cm}$. From the maximum, $\delta^{13} \mathrm{C}$ declines toward the top of the core to the minimum of $-29.02 \pm 0.11 \%$ for all depths above $93 \mathrm{~cm}$.

From 100 to $78 \mathrm{~cm}, \delta^{15} \mathrm{~N}$ (Fig. 8) fluctuates around a low mean of $1.47 \pm 0.67 \%$, then drops to $0.40 \pm 0.30 \%$ at $78 \mathrm{~cm}$. From $78 \mathrm{~cm}$ up to $38 \mathrm{~cm}, \delta^{15} \mathrm{~N}$ increases. From $38 \mathrm{~cm}$ upward to $12 \mathrm{~cm}, \delta^{15} \mathrm{~N}$ is stable and relatively enriched $(4.06 \pm 0.38 \%$ ). However, it drops to $3.5 \%$ around $9-5 \mathrm{~cm}$ before returning to the most enriched values at the surface $(4.7 \%$ oo $)$.

\section{Discussion}

\subsection{Multiproxy interpretation of Tivoli Bays environmental change}

The mid-Hudson Valley marshes, as evidenced by this study, reflect enormous impact from humans. Vegetation composition, invasive species expansion, nutrient dynamics, and sedimentation patterns significantly shift at the boundary of the European

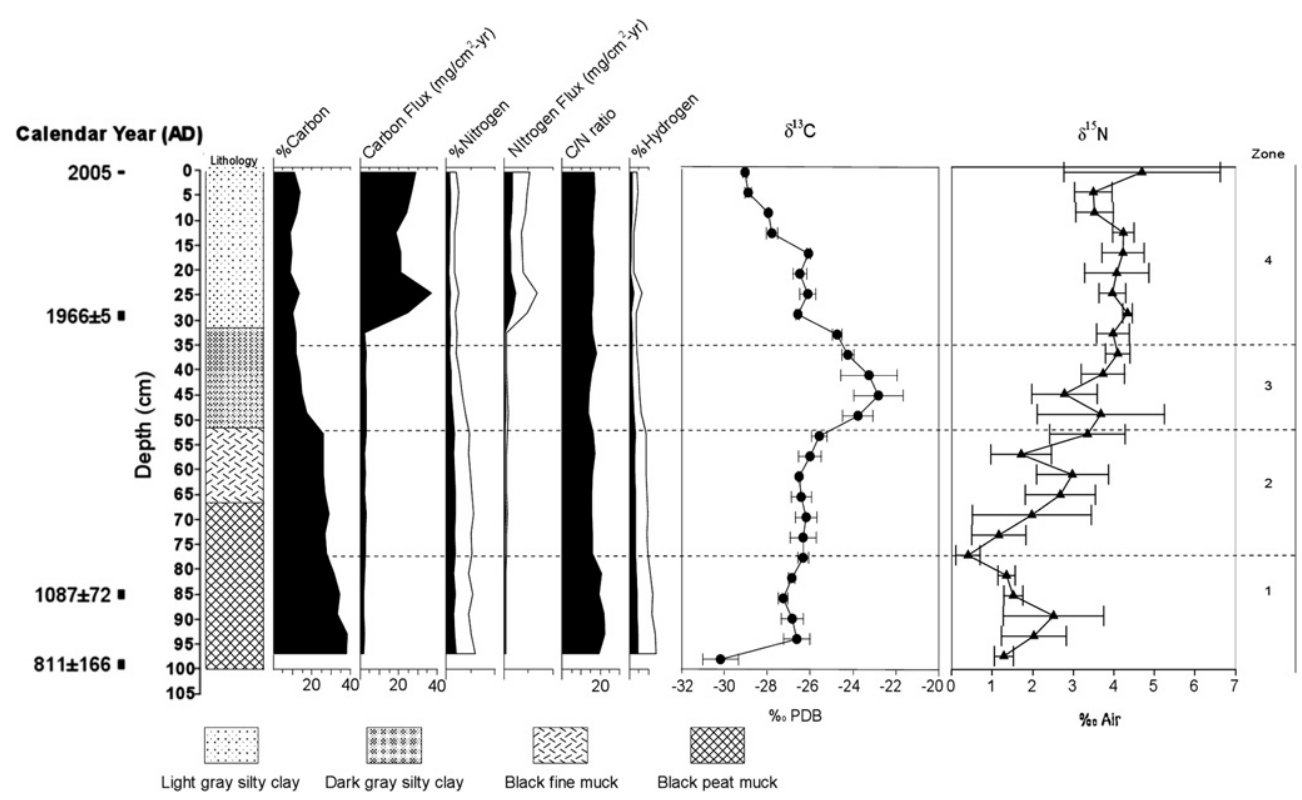

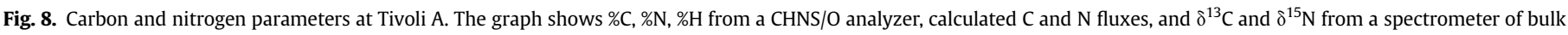
sediment core. 
settlement at $52 \mathrm{~cm}(\sim 1700 \mathrm{AD})$ (Fig. 7). Pollen percentage of native wetland species, including ferns and sedges, decreases by up to $75 \%$ from the pre-European settlement period toward the present. Total percent of invasive species, such as Typha angustifolia, Phragmites australis, and Lythrum salicaria (Fig. 6) increases fivefold. Invasive species expansion is clearly anthropogenic in most cases, as many species were not present or were present at low percentage prior to European settlement. Weedy and woody species also increase by three times their pre-settlement percentages, as supported by disturbance and drier conditions from a 10fold (Fig. 4) higher sedimentation rate and higher inorganic matter input (Fig. 2) during the last century. Based on sediment chemistry, this inorganic matter increase is uniform throughout the marsh, as $\mathrm{Ti}$ and $\mathrm{K}$ increase at all sites when total $\mathrm{Pb}$ and Znare above background level (Figs. 2and 3), indicating influences from humans. Nutrient and carbon concentration, fluxes, and isotopes significantly shift (Fig. 8). Using the vegetation zones previously established based on pollen assemblages, detailed discussion about each time zone follows.

\subsubsection{Pre-European settlement with fires (A.D. 826-1310)}

Forest composition at about $1000 \mathrm{AD}$ is dominated by Quercus and Pinus (Fig. 5). Species that have an advantage in disturbed areas such as Betula and Poaceae are likely indicative of land disturbance from fires, as higher charcoal is observed. High percentage of Carya, a warmth-loving species (Fowells, 1965), supports an increase in temperature. The depth of $84 \mathrm{~cm}$ that is dated to $1087 \pm 72 \mathrm{AD}$ corresponds to the lower charcoal maximum, a feature that is also found in other Hudson River marsh cores at Piermont (Pederson et al., 2005) and Iona (Peteet et al., 2006) and represent the warm, dry Medieval Warm Period (MWP.) This high charcoal peak is likely a result of a regional Hudson Valley MWP recorded on a larger spatial scale in other parts of North America and the globe. For example, Chesapeake records suggest drier conditions prior to the Little Ice Age (LIA) (Brush, 1986, 2001; Cronin et al., 2000, 2010; Cronin and Vann, 2003) and the western US is known to have suffered severe droughts based on tree ring records (Cook et al., 2004). While there is a debate if the MWP is a global phenomenon as the warming is not synchronized at all sites around the globe, many paleoclimatic records suggest widespread climatic anomalies, such as parts of Europe (Mangini et al., 2005), Tasmania (Cook et al., 1991), Asia (Yang et al., 2002), and Africa (Alin and Cohen, 2003) during the same time period.

During this time period prior to the European settlement, the sedimentation rate of $0.05-0.06 \mathrm{~cm} / \mathrm{yr}$ is much lower than the sedimentation rate at the brackish downriver Piermont marsh (Fig. 1, $0.3 \mathrm{~cm} / \mathrm{yr}$ (Pederson et al., 2005)) and is lower than most freshwater tidal marshes (Neubauer, 2008). The sediment is highly organic throughout, suggesting low contribution of any upland sediment source.

If local drought and fire occurred during this period, enhanced erosion from the uplands would likely increase lithogenic input. This may explain the slight decline in percent carbon (Figs. 2 and 8), but the complexity of plant type in net carbon sequestration makes the connection obscure. An increase in the cold indicator, Picea pollen, overlapping the charcoal maximum (Fig. 5) may be a result of increased erosion from the sites further north. Despite the higher charcoal counts compared with the modern deforestation period, the forest and marsh composition of this pre-industrialization interval does not show as much disturbance in species composition as during the subsequent European settlement and industrialization. The presence of aquatic species such as Nymphaea during this presumably warm and dry period suggests that the local plant community may not have been significantly affected by fires. However, the rise of ferns (Osmunda and Polypodiaceae) and
Cyperaceae may indicate a drop in water table at the site that allows the colonization of these genera near shore on exposed riverine mud. Fern expansion was observed at both Piermont and Tivoli supporting a regional hydrological shift.

The $\delta^{13} \mathrm{C}$ signature in marsh sediments reflects the organic matter source, decomposition, and environmental factors (Chmura et al., 1987; Chmura and Aharon, 1995). Chmura et al. (1987) found that $\delta^{13} \mathrm{C}$ in sedimentary carbon in Louisiana marshes was mainly derived from the local dominant vegetation. Since some plant groups have a distinct $\delta^{13} \mathrm{C}$ range and because marsh vegetation has significantly changed at Tivoli based on pollen/macrofossil stratigraphy, vegetational composition is likely the most significant cause of $\delta^{13} \mathrm{C}$ fluctuations at this study site. There exist both $\mathrm{C} 3$ and C4 Cyperaceae which are the dominant pre-European marsh vegetation in this zone. Elevated $\delta^{13} \mathrm{C}$ signature observed in zone 1 (Fig. 8) suggests possible expansion of C4 Cyperaceae as C4 Cyperaceae are reported to be very enriched in $\delta^{13} \mathrm{C}(\sim-12.1$ to $-15.9 \%$ ) (Chmura et al., 1987; Chmura and Aharon, 1995).

The drier condition of the wetland can result in reduced fractionation and decreases in $\delta^{13} \mathrm{C}$ from vegetation change, while the decomposition may increase the ${ }^{13} \mathrm{C}$ content (Chmura et al., 1987; Malamud-Roam and Ingram, 2004). While the $\delta^{13} \mathrm{C}$ is more enriched than in other zones, supporting high decomposition in a dry condition, the inferred lower water level during the warm and dry MWP at Tivoli does not seem to be evident based on $\delta^{13} \mathrm{C}$ as the value is very stable and does not track the charcoal count. Tivoli remained fresh, and the vegetation type in the marsh may not have been significantly altered in comparison to subsequent vegetational change.

There is a higher fluctuation of $\delta^{15} \mathrm{~N}$ around lower mean value of $1.47 \pm 0.67 \%$ below $80 \mathrm{~cm}(\sim 1000 \mathrm{AD})$ (Fig. 8$)$ when charcoal is high (Fig. 5). Burning might have caused the $\mathrm{N}$ fractionation and depleted ${ }^{15} \mathrm{~N}$ (Ansley et al., 2006) during charcoal maxima. Drier conditions would also allow an increase in erosional terrestrial nitrogen input and higher nitrification rate. Both processes can contribute to a heavier ${ }^{15} \mathrm{~N}$ signature than the products of denitrification which occur in conditions of greater anoxia in the sediment (Brandes and Devol, 2002).

\subsubsection{Pre-European forest and climate transition (A.D. \\ 1310- 1700)}

Quercus and Pinus continue to dominate the forest in this region before European settlement (Fig. 5). Quercus bicolor which is found in the woody Tivoli swamp today might have contributed to total Quercus pollen in addition to an upland signal (Kiviat, 1983). Pinus strobus is likely the dominant Pinus species, based on modern assemblages.

Kiviat and Beecher (1991) estimate from an old 1850 map that North Bay was probably dominated by subtidal communities and deep open water. This is supported by our pollen stratigraphy that there were high amounts of aquatic pollen and spores, including Nymphaea and Potamogeton. Cyperaceae, Osmunda, and Polypodiaceae could have resided around the marsh perimeter and on the deltas off several creeks that are present.

Carex cf. aquatilis seeds (Fig. 7) confirm that Cyperaceae was an important marsh component during the pre-European settlement time. This sedge grows well in shallow pools, pond, and near stream margins (Fernald, 1970) and its presence suggests that Tivoli Bays may have been wetter and more open to river flow. Royal fern (Osmunda regalis) is the single Osmunda species in Tivoli Bays today. However, Osmunda spores observed in this zone are comprised of $O$. regalis and at least one other species based on spore texture and size. Thus, higher Osmunda diversity before European settlement is suggested, including possibly 0 . cinnamomea and/or $O$. claytoniana. In contrast to the locally moist marsh condition, a relatively high 
percentage of Carya, Liquidambar, Populus, and charcoal count indicate that regional climate was probably drier as well as warmer at the beginning of this zone during the MWP transition. As charcoal dropped off, mesic species such as Tsuga began to rise, consistent with a transition from drier to wetter conditions. This wetter and cooler period during the LIA is also observed in Piermont (Pederson et al., 2005) and Chesapeake Bay (Brush, 2001; Cronin et al., 2010).

Slightly lower $\mathrm{C} / \mathrm{N}$ ratio early in this zone may be a result of preferential carbon loss from fire. $\delta^{13} \mathrm{C}$ continues to be stable and similar to the previous zone, with values higher than in other zones. Similar to zone 1 , this elevated $\delta^{13} \mathrm{C}$ supports the continuation of a high population of Cyperaceae with enriched ${ }^{13} \mathrm{C} . \delta^{15} \mathrm{~N}$ rebounds and continue to increase as charcoal and fire occurrence decline.

\subsubsection{European settlement, industrialization, and landscape changes (A.D. 1700-<1960s)}

Historic records indicate that the Europeans bought Cruger Island and Tivoli Bays from Native Americans in A.D.1681, but significant logging might not have started until 1688 (Klein, 2001; Philip, 2008). The increase in Ambrosia has been used to successfully indicate the timing of European settlement in the Hudson Highlands and the Hudson Valley (Maenza-Gmelch, 1997; Pederson et al., 2005). Thus, the Ambrosia rise at $54 \mathrm{~cm}$ (Fig. 5), if reflecting regional settlement, suggests the timing of the permanent Dutch settlement starting in the late 17th century (Philip, 2008) which agrees with the age estimation from radiocarbon dates. The major characteristic of this interval is a sharp decline of forest components Quercus, Pinus, Carya, Tsuga, and Liquidambar due to logging with settlement. Charcoal increases probably indicate humaninduced fires. The expansion of Betula supports a disturbance scenario. Early-colonizing herbaceous species, including Poaceae, Chenopodiaceae, Impatiens, and Violaceae became much more abundant (Fig. 5) in response to land clearing. Higher percentage mesic and northern species such as Tsuga prior to this zone and Fagus in the upper part of the zone suggests a moist and cooler climate. Historic records indicate cold winters with high precipitation in the 1800s (Cook and Jacoby, 1977; Klein, 2001).

Lithological change and the reduction of percent carbon are observed in this zone (Fig. 5). At all three Tivoli locations, higher inorganic matter input and higher $\mathrm{K}$, which are indicative of increase of inorganic matter, support the shift in regional sedimentation pattern (Fig. 3). This sediment composition shift is likely due to higher erosion from deforestation during the European settlement and following industrialization. A similar trend is observed during this time frame at Piermont Marsh (Pederson et al., 2005), suggesting regional land-use changes in the estuary. As inorganic deposition rate was higher during this period, it increased the sedimentation rate and raised the elevation of the marsh, making the soils drier with improved drainage. A reduction of aquatic and wetland plants (Nymphaea, Potamogeton, Cyperaceae, Osmunda, and Polypodiaceae) and replacement with shrubby wetland plants (Alnus, Cornus, Cephalanthus and Vitis) supports this inference. Typha angustifolia, along with other invasive species, began to colonize the marsh (Figs. 5and 6).

$\mathrm{C} / \mathrm{N}$ ratios during this settlement interval are lower than in other zones $(p<0.04)$. This reduction indicates higher contribution from low $\mathrm{C} / \mathrm{N}$ sources. Low $\mathrm{C} / \mathrm{N}$ sources include degraded "old soil," aquatic plants, and lower aquatic autotrophs such as plankton and algae. The deforestation could have reduced fresh terrestrial plant input. Subsequent erosion can bring in more well-oxidized upland soil, which has a lower $\mathrm{C} / \mathrm{N}$ content (higher nutrient) than new organic material (Fisher et al., 2003). This initiation of nutrient increase at Tivoli possibly contributed to an increase in invasive species in the wetland.
There is a significant decrease in $\delta^{13} \mathrm{C}(p<0.001)$ and increase of $\delta^{15} \mathrm{~N}(p<0.01)$ compared to the rest of the core just after the European settlement at $48 \mathrm{~cm}$ (Fig. 8). The changes occur at the same depth as the lithological change and a major shift in pollen signifying disturbance. This concurrence supports the hypothesis that $\delta^{13} \mathrm{C}$ and $\delta^{15} \mathrm{~N}$ shifts are due to anthropogenic activities. The depletion of $\delta^{13} \mathrm{C}$ might be a result from a shift in other sediment sources, such as possible increased input from erosion after land clearing or the increase in algae (minimum algae $\delta^{13} \mathrm{C}$ of $-17.9 \%$, (Chmura et al., 1987)) growth due to nutrient fertilization from upland runoff, which is also supported by the $\mathrm{C} / \mathrm{N}$ ratio.

The change and increase in different nitrogen sources is likely the main factor that drives the increasing $\delta^{15} \mathrm{~N}$ trend. Human and animal waste input (enriched in ${ }^{15} \mathrm{~N}$ (Aravena et al., 1993)) to estuarine systems can result in higher $\delta^{15} \mathrm{~N}$ in marsh vegetation (Cole et al., 2004). Increasing population and livestock in the watershed after the European settlement may have increased human and animal waste input which results in the observed higher ${ }^{15} \mathrm{~N}$.

\subsubsection{Reforestation and marsh restoration ( $<1963-$ present)}

Sedimentation rate in this zone at $0.74 \mathrm{~cm} / \mathrm{yr}$ is more than 10 times the sedimentation rate prior to the European settlement, probably as a result of land-use changes and estuarine disturbances. The rate is higher than that of current sea level rise $(0.31 \pm 0.07 \mathrm{~cm} /$ $\mathrm{yr}$ in 1993-2003) and it falls within the range observed sedimentation rates in fresh tidal marshes from various locations (Neubauer, 2008). Regrowth and reforestation is indicated by the resurgence of Quercus, Pinus, and Betula concurrent with the Ambrosia decline in the second half of the twentieth century. However, forest composition is different from pre-settlement as Pinus is less abundant and Betula expands. Vacant and open agricultural land may also result in the continuous growth of weedy species.

In contrast to the Pinus and Quercus reforestation, Tsuga sharply declined and remains low up to the present. In contrast to our pollen record suggesting lack of hemlock recovery, at some New England sites an increase in Tsuga canadensis has been observed as a result of replanting and a decline in logging during recent decades (Orwig and Foster, 1998; McLachlan et al., 2000).

Vegetation of the marsh itself also differs from pre-European time (Figs. 5-7). Woody species, including Salix, Fraxinus, and Cephalanthus, continue to increase, while Cyperaceae, Osmunda, and Polypodiaceae never reach their pre-settlement percentage. Typha angustifolia becomes one of the dominant marsh plants, with more than five times higher pollen percentage than during the presettlement when its pollen was scarce. Tivoli plant surveys in the 1970s and 1980s indicate that T. angustifolia has been a major wetland species for several decades, while woody plants were expanding toward the river (Westad and Kiviat, 1986). T. angustifolia and T. $x$ glauca have become prominent species in North American wetlands and are often considered as weedy, unwanted or invasive with negative impacts on the ecosystem as they spread and develop monocultures, reducing plant diversity (Grace and Harrison, 1986; Houlahan and Findlay, 2004; Shih and Finkelstein, 2008; Vaccaro et al., 2009; Rippke et al., 2010). Based on herbarium and pollen records, Shih and Finkelstein (2008) concluded that Typha spp. has a high invasive tendency in North America. Thirty five out of 45 sites North America showed an increase in T. angustifolia (Typha/Sparganium monads pollen type) in the past 1000 years, concurring with the increasing trend of this species from this study. Piermont Marsh paleoecology indicates a similar expansion of T. angustifolia (Pederson et al., 2005) in recent decades.

Vitis labrusca is very common on woody plants, so Vitis increase may be a result of the expansion of woody species. The presence of 
Asteraceae, Poaceae, Polygonum, and Chenopodiaceae seeds indicate land disturbance and invasion of weedy species which is also observed in the pollen and spore profile. Higher sedimentation rate likely plays a role, as the emergent area of North Bay has increased from 1934 to 1995 near the northwest boundary and along Cruger Island Road based on historical maps.

The most abundant herbs at Tivoli during the last three decades are Impatiens capensis (Impatiens biflora), Lythrum salicaria, Polygonum spp., Osmunda regalis, Pilea pumila, and Viola cucullata (Westad and Kiviat, 1986). In our record, there may be up to a four times reduction in Osmunda spp. while the percentage of Vitis pollen is at least 3 times higher than pre-settlement time, though the seed concentration is stable throughout the core. Small size Poaceae pollen, likely representing Phragmites australis, shows a similar trend as it is invading Tivoli (Kiviat, 1983). Small size Poaceae pollen was present before the settlement, but a minor component. This is supported by other studies suggesting that P. australis was native to North America for at least 3000 years (Orson et al., 1987) based upon rhizome identification. Its aggressive invasion over the last 150 years in the Mid-Atlantic region (Galatowitsch et al., 1999; Rice et al., 2000; Silliman and Bertness, 2004) is attributed to of the introduction of a more aggressive hybrid strain from Eurasia during the early 19th century (Saltonstall, 2002). By DNA sequencing of herbarium collections, the imprint of the introduced strain was shown to be present in the Mid-Atlantic region before 1910. By 1940, only the hybrid strain has been identified (Saltonstall, 2002, 2003). Land disturbances and nutrient enrichment have also been linked to the expansion of this species (Rice et al., 2000; Silliman and Bertness, 2004).

The invasive Lythrum salicaria has been reported to cover large areas during the past three decades (Kiviat, 1983; Westad and Kiviat, 1986; Kiviat and Beecher, 1991). As seen from the pollen record, Lythrum was not significantly present until after European settlement. Myriophyllum pollen, consistently found at a low percentage in the upper zone, is also likely the introduced M. spicatum, the only Myriophyllum species in Tivoli (Westad and Kiviat, 1986). Impatiens pollen and Impatiens capensis seeds increase after the European settlement in similar nature to the increase of other invasive species. The expansion of this species in the fossil record appears unique to Tivoli. This species is native to North America and is considered to be non-invasive in the northeast United States, but it is invasive in Europe (Tabak and Wettberg, 2008). Hybridization of the species with other nonnative Impatiens has not been documented in Northeastern United States, but Tobak and Wettberg suggest there might be a threat of such hybridization. The increase of the species might also be due to the change in environmental factors that favor its expansion and thus close attention to the spread of the species is warranted.

Throughout the upper portion of the core, $\delta^{13} \mathrm{C}$ linearly decreases to below the average pre-historic level. Compilation of the $\delta^{13} \mathrm{C}$ of marsh vegetation reveals that modern invasive and weedy species (i.e. Typha $x$ glauca $(-27.7 \%)$, Phragmites australis ( -24.6 to $-29.4 \%$ ), I. biflora (Impatiens capensis) $(-27.4 \%$ ) are highly depleted in ${ }^{13} \mathrm{C}$ (Chmura and Aharon, 1995; Hornibrook et al., 2000) as are most upland trees. Because terrestrial upland and marsh species have more depleted $\delta^{13} \mathrm{C}$ than aquatic plants, decreasing $\delta^{13} \mathrm{C}$ is consistent with the observed woody species invasion into Tivoli Bays from the pollen and spore record (Fig.6). Degradation of organic matter can result in an enrichment of $\delta^{13} \mathrm{C}$ in the sediment, though selective decomposition might lower $\delta^{13} \mathrm{C}$ as more ${ }^{13} \mathrm{C}$ - depleted organic components such as lignin are better preserved (Chmura et al., 1987; Hornibrook et al., 2000). This can cause an additional effect of lowering the $\delta^{13} \mathrm{C}$ and the gradual $\delta^{13} \mathrm{C}$ decrease near the top of the core as labile-organic matter undergoes more rapid decomposition than old organic matter (Hornibrook et al., 2000). The $\delta^{13} \mathrm{C}$ trend somewhat resembles that of \% organic matter profile $\left(r^{2}=0.7, p<0.01\right)$ in that $\delta^{13} \mathrm{C}$ is more negative with lower organic matter content as higher lithogenic input and sedimentation rate causes the invasion of woody species.

$\delta^{15} \mathrm{~N}$ often parallels wastewater/run off input as well as eutrophication increase in $\delta^{15} \mathrm{~N}$ in macrophytes and marsh sediment of the Hudson estuary and Chesapeake Bay (Cole et al., 2004, 2005; Abreu et al., 2006; Church et al., 2006). In this zone, $\delta^{15} \mathrm{~N}$ remains elevated in comparison to the pre-European settlement period, likely due to the continuation of increased wastewater input. In addition, nitrogen consumption in the United States has increased from near $0 \mathrm{tg} / \mathrm{yr}$ in the 1940's (Vitousek et al., 1997), to $2.74 \mathrm{tg} / \mathrm{yr}$ in 1960 which then exponentially increased to $13.2 \mathrm{tg} / \mathrm{yr}$ in 2007 (Erseus, 2008). Significant increase of agricultural and sewage input to the Hudson Estuary during the last 50 years likely caused eutrophication in the estuary (Howarth et al., 1996). Nitrogen and carbon flux exhibits a significant increase in the last 50 years (Fig. 8), supporting this view.

Anoxic conditions can increase denitrification, and thus enrich ${ }^{15} \mathrm{~N}$ in the sediment further. Evidence of anoxia is also seen as higher carbon and nitrogen fluxes (Fig. 8). Thus, the profile of higher $\delta^{15} \mathrm{~N}$ after the European settlement at Tivoli supports increasing fertilizer usage, wastewater input, and eutrophication. Similar increase in the degree of eutrophication during the same time scale is observed in many other estuaries, including Chesapeake Bay (Cooper and Brush, 1993), Narragansett Bay (Hubeny et al., 2009), and the Great Lakes (Rippke et al., 2010). The shift in $\delta^{15} \mathrm{~N}$ begins at the same time that Typha angustifolia rises and may be linked. This correlation supports the hypothesis that T. angustifolia expansion is fostered by eutrophic and nutrient-rich conditions (Vaithiyanathan and Richardson, 1999; Tanaka et al., 2004).

\subsection{Tivoli Bays in a regional context}

To place the regional ecological changes of the Hudson marshes into a perspective based on historical records, Swaney et al. (2006) suggest that the Hudson watershed was probably heavily forested prior to 1609 . Land along the river was colonized by $1700 \mathrm{AD}$ because the land was easily accessible by boats (Swaney et al., 2006). Swaney et al. also suggest that land clearing and logging of any region along the river took place early, which would explain pollen evidence for arboreal decline in the 17th-18th century at Tivoli and other Hudson River sites (Pederson et al., 2005; Peteet et al., 2006). Palynological records from Hudson Highlands ponds (MaenzaGmelch, 1997) and nearby New Jersey lake (Toney et al., 2003), suggest similar tree declines, and herbs and shrubs increase around $1700 \mathrm{AD}$. The tanning industry started in the 1700s and peaked in the mid 1800s, when the primary resource, Tsuga, declined. Both logging and tanning collapsed from exhaustion of resource and market by the mid 1850 s. In $1880,68 \%$ of the Hudson watershed was farmland, but it has been $70 \%$ reforested by the 1990s (Swaney et al., 2006) and is evident as tree species recovery in pollen records at other sites (MaenzaGmelch, 1997; Pederson et al., 2005). This would explain the rise of tree species at all sites. As expected, pollen percentages of trees are lower than the pre-European values.

Westad and Kiviat (1986) suggested that construction of the Cruger Island Bridge and railroad in 1835 and 1851 may have contributed to higher sedimentation rates in the bays. This development fragmented the bays and slowed down tidal flushing. From our record, a significantly higher inorganic content near the surface at all three Tivoli locations indicates a major landscape change. The railroad construction is the most likely cause of sediment trapping. Higher sedimentation rates may have caused the observed increase 
in drier and woodier species. However, the higher percent of inorganic matter clearly increased when Ambrosia started to rise at Tivoli A, presumably in the eighteenth century. Therefore, it appears that higher inorganic input resulted from the increase in land erosion with settlement somewhat earlier, rather than solely from the subsequent local bridge, road, and railroad constructions.

From this record, Tivoli marsh has stored a significant amount of organic matter, as the \%C in the sediment ranges from 10 to $40 \%$. However, the level drops off after the European settlement. In comparison, the downriver Piermont core has twice as much \%C (20\%) at the surface, and the salt marsh vegetational composition dominated by Spartina patens/Distichlis spicata there is quite different. The LOI at Piermont declined during settlement as the inorganic weight fraction first increased due to erosion but then recovered in the last century as reforestation led to erosional decline (Pederson et al., 2005). A consistently high inorganic fraction at Tivoli in recent centuries may be a result of continued local landscape change rather than a regional effect.

Cook and Jacoby (1977) concluded from a tree ring study that drought during the 1960s was the most severe since 1730 in the Hudson Valley. However, charcoal concentration near the top of this core is five times smaller than during the 11th century maximum. Thus, in comparison, the MWP was probably much drier than recent centuries and additionally humans have suppressed fire.

\section{Conclusions}

In answer to our research questions, the Tivoli Bays paleorecord demonstrates an example of enormous anthropogenic impact of European settlement on an estuarine ecosystem at an NERR site. While upland forest composition recovers somewhat from the preEuropean settlement period, wetland species composition, lithology and function do not recover their pre-European state. Sedimentation rate at Tivoli Bays during the last two centuries $(0.74 \mathrm{~cm} / \mathrm{yr})$ is more than 13 times higher than the pre-settlement period $(0.05 \mathrm{~cm} / \mathrm{yr})$, indicating significant impacts from humaninduced land-use changes. A concurrent significant increase in woody species (Salix spp., Vitis spp., and Alnus spp.) suggests a drier habitat from regional increase of inorganic sediment input. Local marsh vegetation at Tivoli Bays prior to European impact was dominated by sedge (Cyperaceae). Ferns such as Osmunda and Polypodiaceae were also well-represented. Species with high invasive tendency such as Phragmites australis, Typha angustifolia, Lythrum salicaria, and Impatiens capensis all increased up to 5 fold during the last 50-100 years and replaced pre-settlement sedges and ferns. The expansion of these species parallels pollen records in the Hudson Estuary and across North America, confirming the invasiveness of these species. Significant $\delta^{13} \mathrm{C}$ decline after the European settlement at Tivoli Bays confirms the vegetation compositional shifts. $\mathrm{C}$ and $\mathrm{N}$ fluxes, $\delta \mathrm{N}, \% \mathrm{~N}$ profiles support significant anthropogenic influences on nutrient dynamics of the wetland. A significant increase in wastewater input, fertilizer usage, and anoxia are likely linked to invasive species expansion. The finding confirms regional MWP with drought leading to fire and a cooler LIA climate. However, vegetation shifts as a result of these climatic events are smaller than those from human activities.

\section{Acknowledgments}

The project was funded by New York Sea Grant and Hudson River National Estuarine Research Reserves Graduate Fellowship, the National Estuarine Research Reserves Fellowship, and the LamontDoherty Earth Observatory Climate Center. Thanks to Betsy Blair, Chuck Nieder, Geof Eckerlin, and Sarah Fernald who facilitated our field work. We also thank Eric Kiviat and an anonymous reviewer for input and discussion on modern vegetation and history.

\section{References}

Abreu, P., Costa, C., Bemvenuti, C., Odebrecht, C., Graneli, W., Anesio, A., 2006. Eutrophication processes and trophic interactions in a shallow estuary: preliminary results based on stable isotope analysis $\left(\delta^{13} \mathrm{C}\right.$ and $\left.\delta^{15} \mathrm{~N}\right)$. Estuaries and Coasts 29, 277-285.

Alin, S.R., Cohen, A.S., 2003. Lake-level history of Lake Tanganyika, East Africa, for the past 2500 years based on ostracode-inferred water-depth reconstruction. Palaeogeography Palaeoclimatology Palaeoecology 199, 31-49.

Ansley, R.J., Boutton, T.W., Skjemstad, J.O., 2006. Soil organic carbon and black carbon storage and dynamics under different fire regimes in temperate mixedgrass savanna. Global Biogeochemical Cycles 20, GB3006.

Appleby, P.G., Nolan, P.J., Richardson, N., 1992. Self-absorption corrections for welltype germanium detectors. Nuclear Instruments and Methods in Physics Research Section B: Beam Interactions with Materials and Atoms 71, 228-233.

Aravena, R., Evans, M.L., Cherry, J.A., 1993. Stable isotopes of oxygen and nitrogen in source identification of nitrate from septic systems. Ground Water 31, 180-186.

Bindoff, N.L., Willebrand, J., Artale, V., Cazenave, A., Gregory, J., Gulev, S., Hanawa, K., Le Quéré, C., Levitus, S., Nojiri, Y., Shum, C.K., Talley, L.D., Unnikrishnan, D., 2007 Observations: oceanic climate change and Sea level. In: Solomon, S.,D., Qin, M. Manning, Z., Chen, M., Marquis, K.B., Averyt, M., Tignor and H.L. Miller (Eds.), Climate Change 2007: The Physical Science Basis. Contribution of Working Group I to the Fourth Assessment Report of the Intergovernmental Panel on Climate Change.

Brandes, J.A., Devol, A.H., 2002. A global marine-fixed nitrogen isotopic budget: implications for Holocene nitrogen cycling. Global Biogeochemical Cycles 16, 1120.

Brush, G.S., 1986. Geology and paleoecology of Chesapeake Bay: a long-term monitoring tool for management. Journal of the Washington Academy of Sciences 76, 146-160.

Brush, G.S., 2001. Natural and anthropogenic changes in Chesapeake Bay during the last 1000 years. Human and Ecological Risk Assessment 7, 1283-1296.

Burns, D.A., Klaus, J., McHale, M.R., 2007. Recent climate trends and implications for water resources in the Catskill Mountain region, New York, USA. Journal of Hydrology 336, 155-170.

Caraco, N.F., Cole, J.J., Findlay, S.E.G., Fischer, D.T., Lampman, G.G., Pace, M.L., Strayer, D.L., 2000. Dissolved oxygen declines in the Hudson River associated with the invasion of the zebra mussel (Dreissena polymorpha). Environmental Science \& Technology 34, 1204-1210.

Chmura, G.L., Aharon, P., 1995. Stable carbon-isotope signatures of sedimentary carbon in Coastal wetlands as indicators of salinity regime. Journal of Coastal Research 11, 124-135.

Chmura, G.L., Aharon, P., Socki, R.A., Abernethy, R., 1987. An inventory of C-13 abundances in Coastal wetlands of Louisiana, USA - vegetation and sediments. Oecologia 74, 264-271.

Christensen, J.H., Hewitson, B., Busuioc, A., Chen, A., Gao, X., Held, I., Jones, R., K., R.K., K., W.T., L, R., 2007. Regional climate Projections. In: Solomon, S., Qin, D., Manning, M., Chen, Z., Marquis, M., Averyt, K.B., Tignor, M., Miller, H.L. (Eds.), Climate Change 2007: The Physical Science Basis. Contribution of Working Group I to the Fourth Assessment Report of the Intergovernmental Panel on Climate Change. Cambridge University Press, Cambridge, United Kingdom and New York, NY, USA

Church, T.M., Sornmerfield, C.K., Velinsky, D.J., Point, D., Benoit, C., Amouroux, D., Plaa, D., Donard, O.F.X., 2006. Marsh sediments as records of sedimentation, eutrophication and metal pollution in the urban Delaware Estuary. Marine Chemistry 102, 72-95.

Clark, J.S., Patterson, W.A., 1985. The development of a tidal marsh - upland and oceanic influences. Ecological Monographs 55, 189-217.

Cole, M.L., Kroeger, K.D., McClelland, J.W., Valiela, I., 2005. Macrophytes as indicators of land-derived wastewater: application of a delta N-15 method in aquatic systems. Water Resources Research 41.

Cole, M.L., Valiela, I., Kroeger, K.D., Tomasky, G.L., Cebrian, J., Wigand, C. McKinney, R.A., Grady, S.P., da Silva, M.H.C., 2004. Assessment of a delta N-15 isotopic method to indicate anthropogenic eutrophication in aquatic ecosystems. Journal of Environmental Quality 33, 124-132.

Cook, E., Bird, T., Peterson, M., Barbetti, M., Buckley, B., Darrigo, R., Francey, R., Tans, P., 1991. Climatic-change in Tasmania inferred from A 1089-year tree-ring chronology of Huon Pine. Science 253, 1266-1268.

Cook, E.R., Jacoby, G.C., 1977. Tree-ring drought relationships in Hudson Valley, New-York. Science 198, 399-401.

Cook, E.R., Woodhouse, C.A., Eakin, C.M., Meko, D.M., Stahle, D.W., 2004. Long-term aridity changes in the western United States. Science 306, 1015-1018.

Cooper, S.R., Brush, G.S., 1993. A 2,500-Year history of anoxia and eutrophication in Chesapeake Bay. Estuaries 16, 617-626.

Craig, H., 1957. Isotopic Standards for carbon and oxygen and correction factors for mass-spectrometric analysis of carbondioxide. Geochimica Et Cosmochimica Acta $12,133-149$

Cronin, T., Willard, D., Karlsen, A., Ishman, S., Verardo, S., McGeehin, J., Kerhin, R., Holmes, C., Colman, S., Zimmerman, A., 2000. Climatic variability in the eastern 
United States over the past millennium from Chesapeake Bay sediments. Geology 28, 3-6.

Cronin, T.M., Hayo, K., Thunell, R.C., Dwyer, G.S., Saenger, C., Willard, D.A., 2010. The medieval climate anomaly and little ice age in Chesapeake bay and the north Atlantic ocean. Palaeogeography Palaeoclimatology Palaeoecology 297, 299-310.

Cronin, T.M., Vann, C.D., 2003. The sedimentary record of climatic and anthropogenic influence on the Patuxent estuary and Chesapeake Bay ecosystems. Estuaries 26, 196-209.

Dean, W.E., 1974. Determination of carbonate and organic-matter in calcareous sediments and sedimentary-rocks by loss on ignition - Cmparison with other methods. Journal of Sedimentary Petrology 44, 242-248.

Erseus, C., 2008. In: ERS, T.T.V.A., AAPFCO (Association of American Plant Food Control Officials), TFI (The Fertilizer Institute) (Eds.), Fertilizer Use and Price Tables: US Consumption of Plant Nutrients, 2008. USDA.

Faegri, K., Iversen, J., 1975. Textbook of Pollen Analysis. In: Faegri, Knut (Ed.), third revised ed. Blackwell Scientific [etc.], Oxford.

Fernald, M.L., 1970. Gray's Manual of Botany, eighth ed. Van Nostrand Reinhold Co. New York, New York

Findlay, S.E.G., Dye, S., Kuehn, K.A., 2002a. Microbial growth and nitrogen retention in litter of Phragmites australis compared to Typha angustifolia. Wetlands 22,616-625.

Findlay, S.E.G., Kiviat, E., Nieder, W.C., Blair, E.A., 2002b. Functional assessment of a reference wetland set as a tool for science, management and restoration. Aquatic Sciences 64, 107-117.

Finkelstein, S.A., 2003. Identifying pollen grains of Typha latifolia, Typha angustifolia, and Typha xglauca. Canadian Journal of Botany-Revue Canadienne De Botanique 81, 985-990.

Fisher, E., Oldfield, F., Wake, R., Boyle, J., Appleby, P., Wolff, G.A., 2003. Molecular marker records of land use change. Organic Geochemistry 34, 105-119.

Fowells, H.A., 1965. Silvics of Forest Trees of the United States. United States. Dept. of, Agriculture., Washington.

Galatowitsch, S.M., Anderson, N.O., Ascher, P.D., 1999. Invasiveness in wetland plants in temperate North America. Wetlands 19, 733-755.

Grace, J.B., Harrison, J.S., 1986. The biology of Canadian weeds. 73. Typha-latifolia L Typha-angustifolia L and Typha-x glauca GODR. Canadian Journal of Plant Science 66, 361-379

Hardy, E., 1977. Final Tabulation of Monthly Sr-90 Fallout Data, 1954-1976. U.S. Department of Energy.

Hornibrook, E.R.C., Longstaffe, F.J., Fyfe, W.S., 2000. Factors influencing stable isotope ratios in $\mathrm{CH}_{4}$ and $\mathrm{CO}_{2}$ within subenvironments of freshwater wetlands implications for delta-signatures of emissions. Isotopes in Environmental and Health Studies 36, 151-176.

Houlahan, J.E., Findlay, C.S., 2004. Effect of invasive plant species on temperate wetland plant diversity. Conservation Biology 18, 1132-1138.

Howarth, RW Billen, G, Swaney, D, Townsend, A Jaworski, N , Lajtha, $K$, Downing, J.A., Elmgren, R., Caraco, N., Jordan, T., Berendse, F., Freney, J., Kudeyarov, V., Murdoch, P., Zhu, Z.L., 1996. Regional nitrogen budgets and riverine N\&P fluxes for the drainages to the North Atlantic Ocean: natural and human influences. Biogeochemistry 35, 75-139.

Hubeny, J., King, J., Cantwell, M., 2009. Anthropogenic influences on estuarine sedimentation and ecology: examples from the varved sediments of the Pettaquamscutt River Estuary, Rhode Island. Journal of Paleolimnology 41, 297-314.

Isachsen, Y.W., Landing, E., Lauber, J.M., Rickard, L.V., Rogers, 2000. Geology of New York, A Simplified Account. The University of the State of New York, Albany New York.

Jackson, S.T., Hobbs, R.J., 2009. Ecological restoration in the Light of ecological history. Science 325, 567-569.

Kapp, R.O., 2000. Pollen and Spores, second ed. American Association of Stratigraphic Palynologists Foundation.

Kenna, T.C., Nitsche, F.O., Herron, M.M., Mailloux, B.J., Peteet, D., Sritrairat, S. Sands, E., Baumgarten, J., 2011. Evaluation and calibration of a field portable Xray fluorescence spectrometer for quantitative analysis of siliciclastic soils and sediments. Journal of Analytical Atomic Spectrometry.

Kiviat, E., 1983. Fresh-tidal swamp vegetation, Hudson river. Estuaries 6, 279

Kiviat, E., Beecher, E., 1991. Vegetation in the Fresh-tidal Habitats of Tivoli Bays, Hudson River. Hudsonia Ltd.

Klein, M.M., 2001. The Empire State: A History of New York. Cornell University Press; (Cooperstown: New York State Historical Association), Ithaca.

Krishnaswami, S., Lal, D., Martin, J.M., Meybeck, M., 1971. Geochronology of lake sediments. Earth and Planetary Science Letters 11, 407-414.

Maenza-Gmelch, T.E., 1997. Vegetation, climate, and fire during the late-glacialHolocene transition at Spruce pond, Hudson Highlands, southeastern New York, USA. Journal of Quaternary Science 12,15-24.

MaenzaGmelch, T.E., 1997. Holocene vegetation, climate, and fire history of the Hudson Highlands, southeastern New York, USA. Holocene 7, 25-37.

Malamud-Roam, F., Ingram, L.B., 2004. Late Holocene [delta ${ }^{13} \mathrm{C}$ and pollen records of paleosalinity from tidal marshes in the San Francisco Bay estuary, California. Quaternary Research 62, 134-145.

Mangini, A., Spotl, C., Verdes, P., 2005. Reconstruction of temperature in the Central Alps during the past $2000 \mathrm{yr}$ from a delta(18)O stalagmite record. Earth and Planetary Science Letters 235, 741-751.

Martin, A.C., Barkley, W.D., 1973. Seed Identification Manual. University of California Press, Berkeley/London.

McLachlan, J.S., Foster, D.R., Menalled, F., 2000. Anthropogenic ties to latesuccessional structure and composition in four New England hemlock stands. Ecology 81, 717-733.
Mills, E., Strayer, D., Scheuerell, M., Carlton, J., 1996. Exotic species in the Hudson River basin: a history of invasions and introductions. Estuaries and Coasts 19, 814-823.

Monetti, A., 1996. Worldwide Deposition of Strontium-90 Through 1990. US Department of Energy, p. 56

Montgomery, F.H., 1977. Seeds and Fruits of Plants of Eastern Canada and Northeastern United States. University of Toronto Press, Toronto; Buffalo.

NCDC, 2011. US Annual Climatology Summary. National Climatic Data Center. http:// gis.ncdc.noaa.gov/map/lcd/.

Neubauer, S.C., 2008. Contributions of mineral and organic components to tidal freshwater marsh accretion. Estuarine, Coastal and Shelf Science 78 , 78-88.

Nitsche, F.O., Kenna, T.C., Haberman, M., 2010. Quantifying 20th century deposition in complex estuarine environment: an example from the Hudson River. Estuarine, Coastal and Shelf Science 89, 163-174.

Orson, R.A., Warren, R.S., Niering, W.A., 1987. Development of a tidal marsh in a new-England river valley. Estuaries 10, 20-27.

Orwig, D.A., Foster, D.R., 1998. Forest response to the introduced hemlock woolly adelgid in southern New England, USA. Journal of the Torrey Botanical Society 125, 60-73.

Pederson, D.C., Peteet, D.M., Kurdyla, D., Guilderson, T., 2005. Medieval warming little ice age, and European impact on the environment during the last millennium in the lower Hudson valley, New York, USA. Quaternary Research $63,238-249$.

Peteet, D.M., Peteet, D., Pederson, D., Kurdyla, D., Guilderson, T., 2006. Hudson River paleoecology from marshes, Chapter 11. In: Hudson River Fishes and Their Environment. American Fisheries Society Monograph.

Philip, C.O., 2008. Rhinecliff A Hudson River history: the Tangled Tale of Rhinebeck's Waterfront. Black Dome Press Corp, Hensonville, NY.

Rice, D., Rooth, J., Stevenson, J.C., 2000. Colonization and expansion of Phragmites australis in upper Chesapeake Bay tidal marshes. Wetlands 20, 280-299.

Rippke, M.B., Distler, M.T., Farrell, J.M., 2010. Holocene vegetation dynamics of an upper St. Lawrence river wetland: paleoecological evidence for a recent increase in cattail (Typha). Wetlands 30, 805-816.

Robbins, J.A., Edgington, D.N., Kemp, A.L.W., 1978. Comparative (super 210) Pb, (super 137) Cs, and pollen geochronologies of sediments from Lakes Ontario and Erie. Quaternary Research (New York) 10, 256-278.

Saltonstall, K., 2002. Cryptic invasion by a non-native genotype of the common reed, Phragmites australis, into North America. Proceedings of the National Academy of Sciences of the United States of America 99, 2445-2449.

Saltonstall, K., 2003. Microsatellite variation within and among North American lineages of Phragmites australis. Molecular Ecology 12, 1689-1702.

Shih, J.G., Finkelstein, S.A., 2008. Range dynamics and invasive tendencies in Typha latifolia and Typha angustifolia in Eastern North America derived from herbarium and pollen records. Wetlands 28, 1-16.

Silliman, B.R., Bertness, M.D., 2004. Shoreline development drives invasion of Phragmites australis and the loss of plant diversity on New England salt marshes. Conservation Biology 18, 1424-1434.

Stuiver, M., Reimer, P.J., 1993. Extended C-14 data-base and Revised Calib 3.0 C-14 age calibration program. Radiocarbon 35, 215-230.

Swaney, D.P., Limburg, K.E., Stainbrook, K., 2006. Some historical changes in the patterns of population and land use in the Hudson River watershed, Chapter 10 In: Hudson River Fishes and Their Environment. American Fisheries Society Monograph

Tabak, N., Von Wettberg, E.J., 2008. Native and introduced Impatiens of the Northeast: parallel introductions and global spread of temperate jewelweeds. Northeastern Naturalist 15, 159-176.

Tanaka, N., Asaeda, T., Hasegawa, A., Tanimoto, K., 2004. Modelling of the long-term competition between Typha angustifolia and Typha latifolia in shallow water - effects of eutrophication, latitude and initial advantage of belowground organs. Aquatic Botany 79, 295-310.

Templer, P., Findlay, S., Wigand, C., 1998. Sediment chemistry associated with native and non-native emergent macrophytes of a Hudson River marsh ecosystem. Wetlands $18,70-78$.

Toney, J.L., Rodbell, D.T., Miller, N.G., 2003. Sedimentologic and palynologic records of the last deglaciation and Holocene from Ballston Lake, New York. Quaternary Research 60, 189-199.

Vaccaro, L.E., Bedford, B.L., Johnston, C.A., 2009. Litter accumulation promotes dominance of invasive species of cattails (Typha spp.) in Lake Ontario wetlands. Wetlands 29, 1036-1048.

Vaithiyanathan, P., Richardson, C.J., 1999. Macrophyte species changes in the everglades: examination along a eutrophication gradient. Journal of Environmental Quality 28, 1347-1358.

Vitousek, P.M., Aber, J.D., Howarth, R.W., Likens, G.E., Matson, P.A., Schindler, D.W., Schlesinger, W.H., Tilman, G.D., 1997. Human alteration of the global nitrogen cycle: sources and consequences. Ecological Applications 7, 737-750.

Westad, K.E., Kiviat, E., 1986. Flora of freshwater tidal swamps at Tivoli bays Hudson river National estuarine sanctuary. In: Cooper, J.C. (Ed.), Polgar Fellowship Reports of the Hudson River National Estuarine Sanctuary Program 1985. New York State Department of Environmental Conservation, Hudson River Foundation, and U.S. Department of Commerce., New York, pp. III-1-III-20.

Wright, H.E., Mann, D.H., Glaser, P.H., 1984. Piston corers for peat and lake-sediments. Ecology 65, 657-659.

Yang, B., Braeuning, A., Johnson, K.R., Shi, Y.F., 2002. General characteristics of temperature variation in China during the last two millennia. Geophysical Research Letters 29. 